\title{
PENDUGAAN KOEFISIEN RELIABILITAS MULTIDIMENSIONAL PADA MODEL KONSTRUK BERBASIS STRUCTURAL EQUATION MODELING
}

\author{
YOSIKA PUTRI, FERRA YANUAR, DODI DEVIANTO \\ Program Studi Matematika, \\ Fakultas Matematika dan Ilmu Pengetahuan Alam, Universitas Andalas, \\ Kampus UNAND Limau Manis Padang, Indonesia \\ kasiyo yosika5@ymail.com
}

\begin{abstract}
Abstrak. Banyak ditemui peneliti yang mengestimasi data hasil pengukuran yang memiliki struktur multidimensi dengan menggunakan koefisien yang menghendaki asumsi struktur unidimensionalitas pengukuran, misalnya koefisien reliabilitas alpha cronbach, dimana semua indikator yang terdapat dalam model tidak ada pengelompokan pada variabel-variabel latent-nya. Berbeda dengan koefisien reliabilitas multidimensional yang mengharuskan pengelompokan setiap variabel indikatornya terhadap variabel latent-nya. Structural Equation Modeling (SEM) merupakan teknik analisis multivariat yang dapat menganalisis hubungan antara variabel secara kompleks yang terdiri dari model pengukuran dan model struktural. Model pengukuran dapat dilakukan dengan analisis konfirmatori dan model struktural dapat dilakukan de-ngan analisis regresi. Dalam penelitian ini, kedua jenis pendugaan koefisien reliabilitas tersebut digunakan pada konstruk berbasis SEM, dimana koefisien reliabilitas unidimensional akan diterapkan pada koefisien reliabilitas multidimensional.
\end{abstract}

Kata Kunci: Koefisien reliabilitas Alpha Cronbach, koefisien reliabilitas multidimensional, analisis faktor, analisis regresi, Structural Equation Modeling

\section{Pendahuluan}

Pendekatan analisis data penelitian dengan menggunakan Structural Equation Modeling (SEM) telah banyak digunakan dalam berbagai bidang penelitian. SEM merupakan salah satu teknik analisis multivariat yang dapat menganalisis hubungan antara variabel secara kompleks. SEM merupakan gabungan dari model pengukuran dan model struktural. Model pengukuran (measurement model) dilakukan melalui analisis faktor konfirmatori dan model struktural (structural model) dilakukan dengan menggunakan analisis regresi.

SEM dapat memodifikasi model agar dihasilkan model yang sesuai dengan data. Proses modifikasi model yang tepat akan menghasilkan nilai ketepatan estimasi yang lebih akurat. Ketepatan estimasi tersebut dapat diketahui dari suatu reliabilitas alat ukur. Banyak di antara para peneliti yang hanya terpaku pada penggunaan koefisien reliabilitas unidimensional alpha Cronbach dalam mengestimasi reliabilitas tanpa memahami terlebih dahulu asumsi yang mendasari koefisien tersebut [4]. Berbeda dengan koefisien reliabilitas multidimensi, dimana indikator-indikatornya dikelompokkan sesuai konstruk atau variabel latentnya masing-masing. 
Pada kajian ini, kedua jenis pendugaan koefisien reliabilitas tersebut digunakan pada konstruk berbasis SEM, dimana pengukuran konstruk unidimensi akan diterapkan pada konstruk multidimensi. Dengan demikian kedua jenis pendugaan tersebut akan diterapkan pada kasus multidimensi.

\section{Tinjauan Pustaka}

\subsection{Analisis Regresi}

Analisis regresi merupakan analisis statistika yang digunakan untuk mempelajari atau memodelkan hubungan antara variabel terikat dengan variabel bebas.Variabel bebas umumnya digunakan untuk memprediksi nilai variabel terikatnya [1]. Analisis regresi terdiri analisis regresi sederhana yang mempelajari hubungan fungsional antara satu variabel bebas dengan satu variabel terikatnya yang dapat dituliskan sebagai berikut:

$$
Y_{1}=\beta_{0}+\beta_{1} X_{i}+\varepsilon_{i} ; i=1,2,3, \cdots, n
$$

Sedangkan analisis regresi berganda mempelajari hubungan fungsional antara satu variabel terikat dengan beberapa variabel bebas yang dapat dinyatakan sebagai berikut:

$$
Y_{i}=\beta_{0}+\beta_{1} X_{i 1}+\beta_{2} X_{i 2}+\cdots+\beta_{j} X_{i j}+\varepsilon_{i} ; i=1,2,3, \cdots, n ; j=1,2,3, \cdots, m
$$

Dalam bentuk umum dapat ditulis sebagai:

$$
Y=\beta X+\varepsilon
$$

dengan model dugaannya: $Y=\hat{\beta} X+\varepsilon$.

\subsection{Regresi Linier Berganda Multivariat}

Regresi linier berganda multivariat merupakan regresi yang menghubungkan antara $m$ respon, $Y_{1}, Y_{2}, Y_{3}, \cdots, Y_{m}$ dan variabel bebasnya $X_{1}, X_{2}, X_{3}, \cdots, X_{r}$ masingmasing respon diasumsikan memenuhi model regresi:

$$
\begin{aligned}
Y_{1} & =\beta_{01}+\beta_{11} X_{1}+\cdots+\beta_{r 1} X_{r}+\varepsilon_{1}, \\
Y_{2} & =\beta_{02}+\beta_{12} X_{1}+\cdots+\beta_{r 2} X_{r}+\varepsilon_{2}, \\
\vdots & \\
Y_{m} & =\beta_{0 m}+\beta_{1 m} X_{1}+\cdots+\beta_{r m} X_{r}+\varepsilon_{m} .
\end{aligned}
$$

Dengan membuat persamaan di atas ke dalam bentuk matriks, maka diperoleh model regresi berganda multivariate sebagai berikut.

$$
Y_{(n x m)}=X_{(n x(r+1))} \beta_{((r+1) x m)}+\varepsilon_{(n x m)}
$$

dengan modelnya adalah:

$$
Y_{i}=X \beta_{(i)}+\varepsilon_{(i)} ; i=1,2,3, \cdots, m
$$




\subsection{Pendugaan Paramater dengan Metode Kuadrat Terkecil}

Metode kuadrat terkecil merupakan metode yang digunakan untuk menentukan nilai penduga bagi parameter yang menghasilkan jumlah kuadrat residual minimum [1]. Pendugaan ini dilakukan dengan meminimumkan jumlah kuadrat sisaan, yang dapat dinyatakan sebagai berikut:

$$
\sum_{i=1}^{n} e_{i}^{2}=e_{1}^{2}+e_{2}^{2}+\cdots+e_{n}^{2}=e^{T} e
$$

Dari persamaan $\varepsilon=Y-\beta X$ diperoleh:

$$
e^{T} e=Y^{T} Y-2 Y^{T} \hat{\beta} X+X^{T} \hat{\beta}^{T} \hat{\beta} X
$$

Untuk meminimumkan nilai $e^{T} e$, dapat dilakukan dengan menentukan turunan parsial dari persamaan (2.3) terhadap koefisien regresi $\hat{\beta}$, sehingga diperoleh penduga kuadrat terkecil bagi $\hat{\beta}$, yaitu:

$$
\hat{\beta}=\left(X^{T} X\right)^{-1} X^{T} Y
$$

\subsection{Analisis Faktor}

Analisis faktor merupakan analisis statistika yang digunakan untuk mereduksi dimensi data dengan cara menyatakan variabel asal sebagai kombinasi linier sejumlah faktor, sehingga dapat menjelaskan seberapa besar keragaman data yang terdapat dalam variabel asal. Bentuk umum persamaan model analisis faktor sebagai berikut:

$$
X_{i}=l_{i 1} K_{1}+l_{i 2} K_{2}+l_{i 3} K_{3}+\cdots+l_{i r} K_{3}+\varepsilon_{i} ; i=1,2,3, \cdots, n .
$$

Dalam analisis faktor konfirmatori, suatu model yang menjelaskan hubungan antara variabel indikator $X_{1}, X_{2}, X_{3}, \cdots, X_{n}$, dengan variabel latent disebut dengan model pengukuran atau measurement model. Setelah model pengukuran dirumuskan, maka tahap selanjutnya yang harus dilakukan dalam analisis AFK yaitu menentukan faktor loading masing-masing variabel dengan menggunakan metode kemungkinan maksimum (MLE). Selanjutnya dilakukan pengujian model pengukuran dengan cara menguji kesesuaian model untuk mengevaluasi fit atau tidaknya model pengukuran dengan data. Untuk menguji kesesuaian model dapat dilakukan dengan uji Goodness of Fit Indeks (GFI), AGFI, Comparative fit indeks (CFI).

\subsection{Analisis Jalur}

Analisis jalur (path analysis) digunakan untuk menganalisis pola hubungan antar variabel yang bertujuan untuk mengetahui pengaruh langsung atau tidak langsung variabel bebas terhadap variabel terikat. Dalam analisis jalur, hubungan antara variabel dapat dinyatakan dalam sebuah sistem persamaan yang disebut dengan persamaan struktural. Persamaan struktural inilah kemudian digambarkan dalam suatu diagram yang dikenal dengan diagram jalur (path analysis). Untuk membuat model struktural dari diagram jalur tersebut, terdapat suatu koefisien yang menyatakan besarnya pengaruh variabel eksogen ke- $j$ terhadap variabel endogen ke- $i$ yang disebut dengan koefisien jalur. 


\subsection{Struktural Equation Modeling (SEM)}

Model persamaan struktural atau Structural Equation Modeling (SEM) merupakan suatu teknik analisis multivariat yang menggabungkan antara analisis faktor dan analisis jalur. Teknik analisis data dengan menggunakan SEM digunakan untuk menjelaskan secara menyeluruh hubungan (langsung ataupun tidak langsung) antar variabel yang ada dalam penelitian. Dalam SEM, variabel yang akan dimodelkan hubungannya tersebut tidak harus variabel yang dapat terukur langsung atau variabel indikator, tetapi dapat juga variabel latent yang diukur melalui variabelvariabel indikatornya.

Dalam menggunakan analisis SEM terdapat dua variabel yang sering digunakan, yaitu variabel latent dan variabel indikator. Variabel latent sering juga disebut sebagai konstruk yaitu variabel yang tidak dapat diukur secara langsung, yang biasanya digambarkan dengan bulat oval atau elips. sedangkan variabel indikator atau varibel manifest yaitu variabel yang dapat diukur secara langsung, biasanya dilambangkan dengan kotak. SEM juga terdiri dari dua komponen yang membangunnya yaitu model struktural (structural model)dan model pengukuran (measurement model). Model pengukuran merupakan submodel di dalam SEM yang mengidentifikasi konstruk latent dengan indikator-indikatornya yang dapat digunakan untuk mengetahui reliabilitas setiap konstruk yang terdapat di dalam model. Dalam model pengukuran terdapat suatu nilai yang menghubungkan antara variabel latent dengan indikatornya yang disebut dengan faktor loading $(\lambda)$.

Pemodelan dalam SEM merupakan gabungan antara model struktural dengan model pengukuran. Dalam setiap subtruktural dari model struktural selain dipengaruhi oleh variabel latent dan varibel indikator, juga dipengaruhi oleh komponen galat atau eror struktural $(\zeta)$, dan pada variabel latent eksogen eror atau galat pengukurannya dilambangkan dengan ' $\delta$ ' sedangkan untuk variabel latent endogen galat pengukuran dilambangkan dengan' $\varepsilon$ '. Dalam pemodelan SEM terdapat lima langkah yang harus dilakukan yaitu: Spesifikasi model, estimasi model, identifikasi model, evaluasi model, dan interpretasi model.

\subsection{Validasi dan Reliabilitas Suatu Konstruk Ukur}

Kemampuan suatu pernyataan dalam mengukur variabel yang akan diukur dapat diketahui dari validitas suatu konstruk ukur yang dirumuskan sebagai berikut:

$$
r_{h i t}=\frac{n \Sigma X_{i j} Y_{i}-\left(\Sigma X_{i j}\right)\left(\Sigma Y_{i}\right)}{\sqrt{\left(n \Sigma X_{i j}^{2}\right)-\left(\Sigma X_{i j}\right)^{2}} \sqrt{\left(n \Sigma Y_{i j}^{2}\right)-\left(\Sigma Y_{i j}\right)^{2}}}
$$

Sedangkan untuk mengetahui seberapa besar keterandalan suatu alat ukur dapat diketahui dari nilai reliabilitasnya. Koefisien reliabilitas unidimensional dapat diukur menggunakan koefisien alpha Cronbach $\left(C_{\alpha}\right)$ yang didefinisikan sebagai:

$$
C_{\alpha}=\left(\frac{k}{k-1}\right)\left(1-\frac{\sigma_{i}^{2}}{\sigma_{t}^{2}}\right)
$$

Suatu konstruk ukur memiliki reliabilitas baik apabila $C_{\alpha} \geq 0.7$ [6]

SEM juga dapat mengidentifikasi reliabilitas setiap variabel yang terlibat melalui ni- 
lai faktor loading yang dihasilkan, yang dapat dihitung malalui persamaan berikut:

$$
K R=\frac{\left(\sum_{i=1}^{k} \lambda_{i}\right)^{2}}{\left(\sum_{i=1}^{k} \lambda_{i}\right)^{2}+\left(\sum_{i=1}^{k} \delta\right)}
$$

Koefisien reliabilitas berikutnya yaitu koefisien reliabilitas skor komposit McDonald atau koefisien omega $(\omega)$ yang menekankan pada seberapa besar indikator dalam merefleksi atau menjelaskan faktor latent yang diukur. Untuk mendapatkan besarnya koefisien reliabilitas omega, dapat digunakan persamaan dibawah ini.

$$
\omega=\frac{\left(\sum_{i=1}^{k} \lambda_{i}\right)^{2}}{\left(\sum_{i=1}^{k} \lambda_{i}\right)^{2}+\left(\sum_{i=1}^{k} 1-\lambda_{i}^{2}\right)}
$$

Hancock dan Mueller merumuskan koefisien reliabilitas yang diberi nama koefisien reliabilitas konstruk berbobot. Koefisien reliabilitas ini mampu mengakomodasikan bobot yang berbeda antardimensi. Bentuk umum koefisien reliabilitas konstruk berbobot dapat ditulis sebagai berikut:

$$
\Omega_{\omega}=\frac{\sum_{i=1}^{k} \frac{\lambda_{i}^{2}}{\left(1-\lambda_{i}^{2}\right)}}{1+\sum_{i=1}^{k} \frac{\lambda_{i}^{2}}{\left(1-\lambda_{i}^{2}\right)}}
$$

\section{Data dan Metode Penelitian}

Adapun jenis data yang digunakan dalam penelitian ini adalah data sekunder yang diperoleh dari Kajian Eksistensi PT. Asuransi Jasa Raharja di Sumatera Barat yang dilakukan oleh TIM Statistik Jurusan Matematika Universitas Andalas pada bulan Oktober - Desember tahun 2013. Pemodelan tersebut dapat dilakukan melalui kasus pengkajian hubungan antara kualitas pelayanan, kepuasan pelanggan, dan reputasi perusahaan Jasa Raharja. Kualitas pelayanan adalah tingkat keunggulan yang diharapkan dan pengendalian atas tingkat keunggulan tersebut untuk memenuhi keinginan pelanggan. Indikator-indikator yang mempangaruhinya, yaitu penampilan fasilitas fisik perusahaan dan karyawan (PF), kepedulian kepada pelanggan (KP), kemampuan dalam memberikan jasa (KMP), kemauan untuk membantu pelanggan dengan cepat (KMU), serta pengetahuan dan kesopanan dari pegawaipegawai perusahaan (PKP).

Kepuasan pelanggan merupakan tingkat perasaan seseorang setelah membandingkan kinerja atau hasil yang dirasakan dibandingkan dengan harapan yang diinginkan. Indikator-indikator yang mempengaruhinya, yaitu kepuasan terhadap tingkat pelayanan secara keseluruhan $(\mathrm{KK})$, kepuasan terhadap tingkat pelayanan apabila dibandingkan dengan jasa sejenis (KJS), tingkat kepuasan selama menjalin hubungan dengan perusahaan (KHP), kepuasan terhadap iklim antar karyawan (KIK), serta kepuasan terhadap lokasi dari perusahaan (KLP).

Reputasi perusahaan secara langsung membentuk kepercayaan pelanggan terhadap produk atau jasa dari perusahaan yang bersangkutan sehingga akan mempengaruhi pelanggan dalam menentukan pilihan. Beberapa indikator yang dapat digunakan, yaitu kompetensi perusahaan (KP), keunggulan perusahaan (KGL), kepercayaan pelanggan terhadap perusahaan (KPC), dan pengalaman perusahaan 
Tabel 1. Hasil Goodness of Fit Model

\begin{tabular}{|c|c|c|c|}
\hline GOF & Hasil Pengujian & Tingkat Kecocokan yang Diterima & Keterangan \\
\hline GFI & 0.891 & $0 \leq G F I \leq 1.0$ & Fit \\
\hline AGFI & 0.848 & $\geq 0.80$ & Fit \\
\hline CFI & 0.892 & $\geq 0.80$ & Fit \\
\hline
\end{tabular}

(PGL). Ketiga variabel latent tersebut serta indikator-indikator yang mempengaruhinya dianalisis dengan menggunakan teknik analisis SEM yang akan dioperasikan dengan mengunakan program IBM SPSS AMOS 22.0 serta dibantu program SPSS 16.0.

\section{Hasil Pembahasan}

\subsection{Analisis data dengan Teknik SEM}

Model yang akan diestimasi terdiri dari lima variabel manifest eksogen, sembilan variabel manifest endogen, dan 32 parameter. Selanjutnya untuk menguji kecocokan model dapat dilakukan berdasarkan nilai goodness of fit model. Berdasarkan nilai goodness of fit dapat diketahui bahwa model sudah fit dengan data yang ada yang dapat dilihat dari tabel berikut.

\subsection{Koefisien Reliabilitas Multidimensi}

\subsubsection{Reliabilitas Multidimensi untuk Variabel Kualitas Pelayanan}

Untuk koefisien reliabilitas alpha Cronbach dapat diperoleh langsung dengan menggunakan program SPSS 16.0 sebesar 0.529. Sedangkan untuk koefisien reliabilitas skor komposit McDonald, dengan menggunakan program IBM SPSS AMOS 22.0 dan SPSS 16.0 dapat diperoleh: $\left(\sum_{i=1}^{5} \lambda_{i}\right)^{2}=5.189$ dan $\left(\sum_{i=1}^{5} 1-\lambda_{i}^{2}\right)=3.750$, sehingga:

$$
\omega=\frac{\left(\sum_{i=1}^{5} \lambda_{i}\right)^{2}}{\left(\sum_{i=1}^{5} \lambda_{i}\right)^{2}+\left(\sum_{i=1}^{5} 1-\lambda_{i}^{2}\right)}=0.580 .
$$

Untuk koefisien reliabilitas Konstruk $(K R)$ diperoleh hasil yang sama yaitu: $\left(\sum_{i=1}^{5} \lambda_{i}\right)^{2}=5.189$ dan $\left(\sum_{i=1}^{5} \delta\right)=3.750$, sehingga:

$$
K R=\frac{\left(\sum_{i=1}^{5} \lambda_{i}\right)^{2}}{\left(\sum_{i=1}^{5} \lambda_{i}\right)^{2}+\left(\sum_{i=1}^{5} \delta\right)}=0.580 .
$$

Berikutnya untuk koefisien reliabilitas konstruk berbobot $\left(\Omega_{\omega}\right)$, dengan menggunakan program IBM SPSS AMOS 22.0 dan SPSS 16.0 diperoleh:

$\Omega_{\omega}=\sum_{i=1}^{5} \frac{\lambda_{i}^{2}}{\left(1-\lambda_{i}^{2}\right)}=2.815$, sehingga diperoleh:

$$
\Omega_{\omega}=\frac{\sum_{i=1}^{k} \frac{\lambda_{i}^{2}}{\left(1-\lambda_{i}^{2}\right)}}{1+\sum_{i=1}^{k} \frac{\lambda_{i}^{2}}{\left(1-\lambda_{i}^{2}\right)}}=\frac{2.815}{1+2.815}=0.738 .
$$




\subsubsection{Reliabilitas Multidimensi untuk Variabel Kepuasan Pelanggan}

Besarnya koefisien reliabilitas alpha Cronbach dapat diperoleh langsung dengan menggunakan program SPSS 16.0 sebesar 0.802. Sedangkan untuk koefisien reliabilitas skor komposit McDonald, dengan menggunakan program IBM SPSS AMOS 22.0 dan SPSS 16.0 diperoleh: $\left(\sum_{i=1}^{5} \lambda_{i}\right)^{2}=11.916$ dan $\left(\sum_{i=1}^{5} 1-\lambda_{i}^{2}\right)=2.533$ sehingga:

$$
\omega=\frac{\left(\sum_{i=1}^{5} \lambda_{i}\right)^{2}}{\left(\sum_{i=1}^{5} \lambda_{i}\right)^{2}+\left(\sum_{i=1}^{5} 1-\lambda_{i}^{2}\right)}=0.825 .
$$

Untuk koefisien reliabilitas Konstruk $(K R)$ diperoleh hasil yang sama yaitu: $\left(\sum_{i=1}^{5} \lambda_{i}\right)^{2}=11.916$ dan $\left(\sum_{i=1}^{5} \delta\right)=2.530$, sehingga:

$$
K R=\frac{\left(\sum_{i=1}^{5} \lambda_{i}\right)^{2}}{\left(\sum_{i=1}^{5} \lambda_{i}\right)^{2}+\left(\sum_{i=1}^{5} \delta\right)}=0.825 .
$$

Berikut untuk koefisien reliabilitas konstruk berbobot $\left(\Omega_{\omega}\right)$, dengan menggunakan program IBM SPSS AMOS 22.0 dan SPSS 16.0 diperoleh: $\Omega_{\omega}=\sum_{i=1}^{5} \frac{\lambda_{i}^{2}}{\left(1-\lambda_{i}^{2}\right)}=5.738$, sehingga:

$$
\Omega_{\omega}=\frac{\sum_{i=1}^{k} \frac{\lambda_{i}^{2}}{\left(1-\lambda_{i}^{2}\right)}}{1+\sum_{i=1}^{k} \frac{\lambda_{i}^{2}}{\left(1-\lambda_{i}^{2}\right)}}=\frac{5.738}{1+5.738}=0.852 .
$$

\subsubsection{Reliabilitas Multidimensi untuk Variabel Reputasi Perusahaan}

Untuk koefisien reliabilitas alpha Cronbach dapat diperoleh langsung dengan menggunakan program SPSS 16.0 sebesar 0.800. Sedangkan untuk koefisien reliabilitas skor komposit McDonald, dengan menggunakan program IBM SPSS AMOS 22.0 dan SPSS 16.0 diperoleh: $\left(\sum_{i=1}^{5} \lambda_{i}\right)^{2}=8.168$ dan $\left(\sum_{i=1}^{5} 1-\lambda_{i}^{2}\right)=1.954$, sehingga:

$$
\omega=\frac{\left(\sum_{i=1}^{5} \lambda_{i}\right)^{2}}{\left(\sum_{i=1}^{5} \lambda_{i}\right)^{2}+\left(\sum_{i=1}^{5} 1-\lambda_{i}^{2}\right)}=0.807 .
$$

Untuk koefisien reliabilitas Konstruk $(K R)$ diperoleh hasil yang sama yaitu: $\left(\sum_{i=1}^{5} \lambda_{i}\right)^{2}=8.168$ dan $\left(\sum_{i=1}^{5} \delta\right)=1.954$, sehingga:

$$
K R=\frac{\left(\sum_{i=1}^{5} \lambda_{i}\right)^{2}}{\left(\sum_{i=1}^{5} \lambda_{i}\right)^{2}+\left(\sum_{i=1}^{5} \delta\right)}=0.807 .
$$

Berikut untuk koefisien reliabilitas konstruk berbobot $\left(\Omega_{\omega}\right)$, dengan menggunakan program IBM SPSS AMOS 22.0 dan SPSS 16.0 diperoleh: $\Omega_{\omega}=$ $\sum_{i=1}^{5} \frac{\lambda_{i}^{2}}{\left(1-\lambda_{i}^{2}\right)}=4.253$, sehingga:

$$
\Omega_{\omega}=\frac{\sum_{i=1}^{k} \frac{\lambda_{i}^{2}}{\left(1-\lambda_{i}^{2}\right)}}{1+\sum_{i=1}^{k} \frac{\lambda_{i}^{2}}{\left(1-\lambda_{i}^{2}\right)}}=\frac{4.253}{1+4.253}=0.809 .
$$

Hasil uraian diatas dapat dirangkum dalam Tabel 2.

Berdasarkan Tabel 1, model yang dihipotesiskan telah memenuhi seluruh kriteria yang dibutuhkan, sehingga model dapat diterima dan modifikasi model tidak perlu 
Tabel 2. Rangkuman Hasil Penelitian

\begin{tabular}{|c|c|c|c|c|}
\hline Reliabilitas & $\alpha$ & $\omega$ & $K R$ & $\Omega_{w}$ \\
\hline Kualitas Pelayanan & 0.529 & 0.580 & 0.580 & 0.738 \\
\hline Kepuasan Nasabah & 0.802 & 0.825 & 0.825 & 0.852 \\
\hline Reputasi Perusahaan & 0.800 & 0.807 & 0.807 & 0.809 \\
\hline
\end{tabular}

dilakukan. Dari output SPSS 16.0 diperoleh hubungan antara kualitas pelayanan dan kepuasan pelanggan memiliki nilai $\mathrm{p}<0.05$, hal ini menyatakan bahwa terdapat hubungan yang signifikan antara kualitas pelayanan dengan kepuasan pelanggan. Semakin bagus atau tinggi kualitas pelayanan maka kepuasan pelanggan terhadap kualitas pelayanan juga akan semakin tinggi, dan sebaliknya. Begitu juga dengan hubungan antara kepuasan pelanggan dan reputasi perusahaan memiliki nilai $\mathrm{p}<0.05$, hal ini juga menyatakan bahwa terdapat hubungan yang signifikan antara kepuasan pelanggan dengan reputasi perusahaan. Semakin tinggi tingkat kepuasan pelanggan maka reputasi perusahaan juga akan semakin baik.

Berdasarkan Tabel 2 dapat dijelaskan bahwa koefisien reliabilitas alpha Cronbach $\left(C_{\alpha}\right)$, koefisien reliabilitas konstruk $(K R)$, dan koefisien omega $(\omega)$ memiliki nilai reliabilitas yang kurang dari 0.7 . Hal ini terjadi sebagai akibat dari nilai loading beberapa indikator yang mempengaruhi variabel kualitas pelayanan memiliki nilai yang rendah, sehingga menyebabkan rendahnya nilai reliabilitas yang dihasilkan. Walaupun demikian, variabel kualitas pelayanan sudah dikatakan memiliki reliabilitas yang baik. Hal ini dibuktikan dari nilai koefisien reliabilitas konstrak berbobot $\left(\Omega_{\omega}\right)$ yang memiliki nilai reliabilitas lebih dari 0.7 . Ini berarti bahwa variabel kualitas pelayanan mampu dijelaskan oleh indikator-indikator yang mempengaruhinya. Begitu juga dengan variabel kepuasan pelanggan dan reputasi perusahaan yang memiliki nilai reliabilitas yang baik yang ditunjukkan dari nilai reliabilitas pada masing-masing koefisien reliabilitasnya yaitu pada koefisien reliabilitas alpha Cronbach $\left(C_{\alpha}\right)$ dan pada ketiga koefisien multidimensi yang ada $\left(K R, \omega, \Omega_{\omega}\right)$ yang masingmasingnya memiliki nilai reliabilitas di atas 0.7. Ini menunjukkan bahwa variabel kepuasan pelanggan dan reputasi perusahaan mampu dijelaskan oleh indikatorindikator dari masing-masing variabel latent tersebut.

Berdasarkan Tabel 2 juga dapat dilihat bahwa koefisien reliabilitas multidimensi $\left(K R, \omega, \Omega_{\omega}\right)$ memiliki nilai yang lebih tinggi dibandingkan dengan nilai koefisien reliabilitas alpha Cronbach $\left(C_{\alpha}\right)$. Ini berarti bahwa dalam penerapannya, koefisien reliabilitas multidimensi lebih akurat atau lebih tepat dibandingkan koefisien reliabilitas alpha Cronbach $\left(C_{\alpha}\right)$, serta antara kedua koefisien reliabilitas yang digunakan dalam pendugaan memiliki hubungan yang linier. Hal ini terlihat dari nilai antara masing-masing koefisien reliabilitas yang memiliki nilai yang hampir sama.

\section{Kesimpulan}

Penerapan konsep pendugaan koefisien reliabilitas multidimensi dengan menggunakan SEM dapat dilakukan dalam berbagai bidang ilmu, salah satunya di bidang ilmu sosial yang digunakan untuk menganalisis Kajian Eksistensi PT. Asuransi Jasa Raharja di Sumatera Barat. Berdasarkan hasil yang diperoleh dapat disim- 
pulkan koefisien reliabilitas multidimensi memiliki nilai reliabilitas yang lebih tinggi dibandingkan koefisien reliabilitas alpha Cronbach. Hal ini berarti koefisien reliabilitas multidimensi lebih tepat atau lebih akurat apabila dibandingkan dengaan koefisien reliabilitas alpha Cronbach.

Saran untuk penelitian selanjutnya, akan lebih baik apabila menggunakan jumlah sampel yang lebih besar dan populasi yang lebih luas, serta estimasi reliabilitas ini hendaknya diuji lebih lanjut dengan menggunakan rumus atau pendekatan metode lainnya yang tidak berbasis SEM.

\section{Ucapan Terima kasih}

Penulis mengucapkan terima kasih kepada Ibu Riri Lestari, M.Si, Ibu Rini Andaria, M.Si dan Ibu Dr. Yanita yang telah memberikan masukan dan saran sehingga paper ini dapat diselesaikan dengan baik.

\section{Daftar Pustaka}

[1] Draper, N. R dan H.Smith. 1992. Analisis Regresi. Pt. Gramedia, Jakarta

[2] Kusnedi. 2008. Model-Model Persamaan Struktural Satu dan Multigroup Sampel dengan Lisrel. Alfabeta, Bandung

[3] Nawangsari, A. 2011. Structural Equation Modeling Konsep dan Aplikasi Menggunakan Program Amos. Universitas Yogyakarta, Yogyakarta

[4] Socan, G. 2000. Assessment of Reliability when Test Items Are Not Essentially T-Equivalent. Development in Survey Methodology, Ljubljana: FDV

[5] Suryabrata, Sumadi. 2005. Pengembangan Alat Ukur Psikologi. Yogyakarta

[6] Widhiarso, Wahyu. 2009. Koefisien Reliabillitas pada pengukuran kepribadian yang bersifat multidimensi. Psikobuana. 1(1): $39-48$ 